\title{
INVESTIGATING THE USE ACTION LEARNING APPROACHES IN CIVIL ENGINEERING AND CONSTRUCTION STUDIES: A CASE OF SKILLS CENTRE
}

\author{
Khojane Geoffrey Mokhothu, Charles S Masoabi, \& Alfred H Makura \\ Central University of Technology Free State (South Africa)
}

\begin{abstract}
Civil Engineering and Construction studies are the study fields that embraces practical and theory. While action learning approaches is encompassed with a myriad of teaching and learning methods to closed the deficits. The research aims to investigate the use of action learning approaches in Civil engineering and Construction studies. while the objective of the research is to assess the extent to which action learning approaches is employed in teaching practical and content knowledge in Civil Engineering and Construction studies. The research used a mixed-method approach comprising quantitative and qualitative methodology to collect data. Questionnaire and face to face semi-structured interview were used as the tools to gather data. Participants were all 10 lecturers and assistance lecturers, males and females from different culture, age and race. Findings of the research revealed that lecturers are using action learning approaches unaware. The research, suggests that all lecturer at the skills centres should be afforded opportunities to attend facilitations and assessor courses or Universities of Technology should develop a short education methodology for them of which it will equip their teaching and learning skills.
\end{abstract}

Keywords: Action learning, civil engineering and construction, skills centre.

\section{Introduction}

Action learning approaches are classified as suitable and effective method to promote skills development and theory awareness. Hence, Civil Engineering and Construction studies at skill centres are confided to address high volume of practical work and less volume of theory. In support of the above mentioned statement, the DHET (2019:11) in their mission statement states that (To improve access to occupations in high demand and priority skills aligned to supporting economic growth, employment creation and social development whilst also seeking to address systemic considerations). Therefore, the paper seeks to investigate the use of Action Learning approaches in Civil Engineering and Construction studies to achieve the mission.

\section{The conceptualisation of the study}

\subsection{Action learning}

"There is no learning without action and no (sober and deliberate) action without learning" (Peddle, 1991). The Action Learning Approach is described in this study as an approach to working with and developing people on a real project or problem as a way to learn." Participants collaborate in small sets to solve their dilemma and learn how to apply what they have learned (Marsick and O'Neil, 1999:6; Mughal 2016).

\subsection{Skill centre}

Skill Centre are designed to provides the content and high skills to be taught across the period of learning (Western Cape Government, nd:1). The skills centre objective is to learn the skills needed by students and students can learn the skills of students based on the school area of the Urban Area, Central Region, and Rural Areas.

\subsection{Civil engineering and construction studies}

In this study Civil Engineering and Construction refers to Building environment in general which include skills such as: bricklaying, tilling, woodworking, plumbing and many others (Mokhothu, 2018:323). The Department of Higher Education (DHET) and Training asserts that Civil Engineering and Building Construction course covers construction, masonry building and woodworking; design, drainage and sanitation in a practical, theoretical, management and design environment. This course integrates academic knowledge and theory with practical skills and values (DHET, 2015:8; Maeko, 2020:38). 


\section{The aim of the study}

The aim of the study is to investigate the use of Action learning approaches in Civil Engineering and Construction studies at skills centre level.

\section{The objective}

The main objective of the research is to assess the extent to which action learning approaches is employed in teaching practical and content knowledge in Civil Engineering and Construction studies.

\section{Proposition}

Action Learning Approaches play a pivotal role in promoting effective teaching and learning of practical work and theory in Civil Engineering and Construction studies.

\section{Methodology}

\subsection{The context of the study}

The researcher visited theory classes and workshops where teaching and learning for Civil Engineering and Construction studies occurs all the time. Classes and workshops are allocated for the following subjects: Bricklaying and plastering, Plumbing, woodworking (carpentry and cabinet making). At the end of the tour the instructors were presented with the questionnaires.

\subsection{Participants}

All study participants were instructors responsible for Civil Engineering and Construction studies: Bricklaying and plastering, Plumbing, woodworking (carpentry and cabinet making) at the skills centre. The total number of participants was 10 which comprises of $2(20 \%)$ females and $8(80 \%)$ males from diverse ethnic group. Each subjects were allocated 1 instructor responsible for theory and practical and 1 responsible for practical only assistant instructor.

\subsection{Procedures}

All participants were asked to complete the questionnaire for two days as the research process was scheduled for seven days. Then on the third day, the research began with the face to face interview to gather data using voice recorder to produce qualitative data through transcribing. The interview was scheduled for one hour for two days. All questionnaires were received and all were completed then quantitative was produced. Both quantitative and qualitative data were produced, analysed and presented.

\section{Results presentation, interpretation and discussion}

\subsection{Quantitative data}

Table 1 below present the results obtained from the questionnaire.

Table 1. Action Learning Approached.

\begin{tabular}{|c|c|c|c|c|c|}
\hline \multirow[t]{2}{*}{ B } & \multicolumn{5}{|c|}{$\begin{array}{l}\text { The extent lecturers use action learning approaches in Civil Engineering and Construction studies at } \\
\text { TVET colleges }\end{array}$} \\
\hline & & SA (1) & A (2) & D (3) & SD (4) \\
\hline & & \multicolumn{4}{|c|}{ No. response (\%) } \\
\hline 1 & $\begin{array}{l}\text { I understand the difference and relationship between } \\
\text { approaches and methods of Action Learning. }\end{array}$ & $4(40 \%)$ & $\mathbf{0}$ & $\mathbf{0}$ & $6(60 \%)$ \\
\hline 2 & $\begin{array}{l}\text { I use case studies as a teaching and learning technique } \\
\text { frequently in my class. }\end{array}$ & $\begin{array}{c}10 \\
(100 \%) \\
\end{array}$ & $\mathbf{0}$ & $\mathbf{0}$ & $\mathbf{0}$ \\
\hline 3 & $\begin{array}{l}\text { I use simulations frequently as a teaching and learning } \\
\text { technique in my class. }\end{array}$ & $\mathbf{0}$ & $\begin{array}{c}2 \\
(20 \%)\end{array}$ & $\mathbf{0}$ & $\begin{array}{c}\mathbf{8 0} \\
(\mathbf{8 0} \%) \\
\end{array}$ \\
\hline 4 & $\begin{array}{l}\text { I use projects frequently as a technique to teach other aspect of } \\
\text { the content. }\end{array}$ & $\begin{array}{c}10 \\
(100 \%)\end{array}$ & $\mathbf{0}$ & $\mathbf{0}$ & $\mathbf{0}$ \\
\hline 5 & $\begin{array}{l}\text { I use research as a teaching and learning technique frequently } \\
\text { to promote critical thinking in my class. }\end{array}$ & $\mathbf{0}$ & $\mathbf{0}$ & $\mathbf{0}$ & $\begin{array}{c}10 \\
(100 \%) \\
\end{array}$ \\
\hline 6 & $\begin{array}{l}\text { I use demonstration method as the main teaching method in my } \\
\text { class. }\end{array}$ & $\begin{array}{c}10 \\
(100 \%) \\
\end{array}$ & $\mathbf{0}$ & $\mathbf{0}$ & 0 \\
\hline 7 & $\begin{array}{l}\text { I use problem solving method to teach integration of content } \\
\text { knowledge and practical work in my class. }\end{array}$ & $\mathbf{0}$ & $\mathbf{0}$ & $\mathbf{0}$ & $\begin{array}{c}10 \\
(100 \%) \\
\end{array}$ \\
\hline 8 & $\begin{array}{l}\text { I use technological process method to teach integration of } \\
\text { content knowledge and practical work in my class. }\end{array}$ & $5(50 \%)$ & $\begin{array}{c}1 \\
(10 \%)\end{array}$ & $\begin{array}{c}1 \\
(10 \%)\end{array}$ & $3(30 \%)$ \\
\hline
\end{tabular}

Strongly agree (SA), Agree (A), Disagree (D), Strongly Disagree (SD) 
Table 1 above presents the results from the questionnaire, which indicates that at question 1 high number of instructors $n=6(60 \%)$ strongly disagree, while $n=40 \%$ indicates that strongly agree. Question 2 show that all instructors $n=10(100 \%)$ strongly agree. Majority of instructors $80(80 \%)$ at question 3 are strongly disagree with the statement. At question 4 and 6 all instructors $n=10(100 \%)$ strongly agree. instructors in majority $n=10(100 \%)$ are strongly disagree with the statement. All aforesaid results indicate that majority of the instructor did not receive formal training of teaching and learning methodology. Therefore, the results prove the statement pronounced by Makole (2015: iv) that skills programme requires instructors or facilitators who are competent in totality (theoretical and practical) content. The study revealed that skills programme instructors perform excellent work in nourishing practical skills the only deficit is they are not qualified and lack pedagogical skill.

\subsection{Interview Questions (Qualitative)}

Table 2 Semi- structured.

\begin{tabular}{|c|}
\hline 1. What is your view regarding the use of ALA in CEC studies at Skills centre? \\
\hline $\begin{array}{l}\text { Instructor A: I'm really not sure what is action learning exactly but I teach theory } \\
\text { and more practical using teaching methods } \\
\text { Instructor B: It is important because you learn while you are on action } \\
\text { Instructor C: Should be use because of practical, practical needs action } \\
\text { Instructor D: I think we have to use it if action learning is all about action and learn } \\
\text { Instructor E: I use it because my learners are always hands-on }\end{array}$ \\
\hline 2. What are your favourite techniques when implementing ALA in CEC studies? \\
\hline $\begin{array}{l}\text { Instructor A: I'm not sure what are the techniques but I like demonstration method } \\
\text { Instructor B: Demonstration } \\
\text { Instructor C: I'm not sure really, I just teach and show them if they don't } \\
\quad \text { understand } \\
\text { Instructor D: Demonstration } \\
\text { Instructor E: Demonstration, hand-on and simulation }\end{array}$ \\
\hline 3. What makes them your favourite techniques of action learning in CEC studies? \\
\hline $\begin{array}{l}\text { Instructor A: Because, I always get a chance to work with my learners } \\
\text { Instructor B: To make sure that your learners see what you want them to do } \\
\text { Instructor C: Because I can show them skills } \\
\text { Instructor D: That's an only method we use in skill centre } \\
\text { Instructor E: Yes as an assessor those are the most significant } \\
\text { methods/techniques to use during skills development }\end{array}$ \\
\hline 4. Can you explain how do you use these favourite techniques of ALA in your CEC studies class? \\
\hline $\begin{array}{l}\text { Instructor A: I show my learners how to set-out foundation then they do the same } \\
\text { Instructor B: Demonstrate the lesson then they follow me } \\
\text { Instructor C: They learn what I do and I give them a chance to do again and again } \\
\text { Instructor D: I demonstrate first then they follow } \\
\text { Instructor E: I explain; I show them then I allow them to practice until they master } \\
\text { the skill }\end{array}$ \\
\hline $\begin{array}{l}\text { 5. Which teaching and learning methods or techniques you use during application } \\
\text { of ALA in CEC studies class? }\end{array}$ \\
\hline $\begin{array}{l}\text { Instructor A: I like demonstration, presentation and gaming } \\
\text { Instructor B: Demonstration and Video's } \\
\text { Instructor C: Demonstration and others maybe I mix, I don't know! } \\
\text { Instructor D: Demonstration and presentation of videos } \\
\text { Instructor E: Demonstration, Visual and Question and answer(discussion) method }\end{array}$ \\
\hline
\end{tabular}

Table 2 above presents the results from semi-structured interview. The interview in general results demonstrated that instructors are aware but not aware that, they are using action learning approaches for effective teaching and learning in everyday teaching and learning activities. The above statement compensates Pedler (1991) in Mokhothu (2020:166) when state that "There is no learning without action and no sober and deliberate action without learning". 


\section{Conclusion}

In conclusion the study has shown that skills centre are the main hub of skills production and recycling or rehabilitation of communities' technical skills in the country South Africa. As the study has exposed, the effective and sustainable knowledge and skills transferred by the instructors to the learners without formal teaching qualifications but they have only training acquired form the skills centre. Therefore, the study recommend that different government department involved in skills centre should initial programmes that allows skills centre instructors to acquire formal teaching qualification and assessor certificate.

\section{References}

Maeko, MSA 2020. Teaching and Learning Through Hands-on Activities in Civil Technology Teacher Training Programmes at South African Universities. Journal of Human Ecology, 71(1-3): 38-48

Makole, KZ. 2015. The Implementation of the National Certificate Vocational Programme at Tshwane North FET College. MM Dissertation. Johannesburg: University of Witwatersrand.

Mokhothu, KG 2018. The Effectiveness of Demonstrational Method in Promoting Student Centred Method: Case Study, C. Mafalda (Ed). Proceedings of $6^{\text {th }}$ International Conference on New Developments (END), 27-29 June, 2018. Budapest Hungary. 322-325. ISBN: 978-989-99864-8-0.

Mokhothu, KG 2020. Investigating the Impact of Learn by doing in Civil Technology Class: Students Action, C. Mafalda (Ed). Proceedings of $8^{\text {th }}$ International Conference on New Developments (END), 27-29 June, 2020. Porto Portugal. 164-167. ISBN: 978-54815-2-1.

Pedler, M 1991. Action Learning in Practice, $2^{\text {nd }}$ edn. Brookfield, VT: Gower. 